\title{
Aa. Vv., Poètes et poétesses dans le roman (Actes de la journée d'études du 8 décembre 2005)
}

\section{Maria Colombo Timelli}

\section{(2) OpenEdition}

1 Journals

\section{Édition électronique}

URL : http://journals.openedition.org/studifrancesi/8169

DOI : 10.4000/studifrancesi.8169

ISSN : 2421-5856

Éditeur

Rosenberg \& Sellier

\section{Édition imprimée}

Date de publication : 1 mai 2009

Pagination : 145

ISSN : 0039-2944

\section{Référence électronique}

Maria Colombo Timelli, «Aa. Vv., Poètes et poétesses dans le roman (Actes de la journée d'études du 8 décembre 2005) », Studi Francesi [En ligne], 157 (LIII | I) | 2009, mis en ligne le 30 novembre 2011, consulté le 11 janvier 2021. URL : http://journals.openedition.org/studifrancesi/8169 ; DOI : https:// doi.org/10.4000/studifrancesi.8169

Ce document a été généré automatiquement le 11 janvier 2021.

\section{(c)}

Studi Francesi è distribuita con Licenza Creative Commons Attribuzione - Non commerciale - Non opere derivate 4.0 Internazionale. 


\title{
Aa. Vv., Poètes et poétesses dans le roman (Actes de la journée d'études du 8 décembre 2005)
}

\author{
Maria Colombo Timelli
}

\section{RÉFÉRENCE}

Poètes et poétesses dans le roman (Actes de la journée d'études du 8 décembre 2005), «Bien dire et bien aprandre. Revue de Médiévistique», 25, 2007.

1 Marie-Madeleine CASTELLANI (Lyrique et narratif dans les "Ovidiana", pp. 17-32) montre la place de la lyrique dans trois récits en vers inspirés d'Ovide: le Lai de Narcisse, où la plainte finale de Dané n'est pourtant pas marquée sur le plan formel, Philomela, où l'auteur fait une place importante à la musique et au chant, Pyrame et Tisbé enfin, où la communication même entre les protagonistes se fait par le biais de la forme lyrique.

Francine MORA (La mise en scène lyrique de la mort du poète dans le "Roman du Châtelain de Coucy", pp. 33-47) souligne l'importance de la mort du poète-protagoniste en comparant la forme et la fonction des deux dernières insertions lyriques du roman: la chanson de croisade composée par le châtelain, et le virelai, qu'il faut en revanche attribuer à 'Jakemes'. La lettre qui accompagne le don du cœur et le congé de l'amant à la dame confirment par ailleurs un subtil jeu de renvois entre l'auteur du XIII ${ }^{\mathrm{e}}$ siècle et le poète-troubadour, ainsi que l'intertextualité avec notamment le Tristan en prose et le congé d'Adam de la Halle.

Catherine GAULLIER-BOUgASSAS (Alexandre et les poètes, ou le lyrisme dans le roman épique médiéval: le "Restor du Paon" et le "Parfait du Paon", pp. 49-69) souligne le rôle de la poésie et de la musique dans le cycle du Paon (XIV ${ }^{\mathrm{e}}$ siècle): dans le Restor par l'introduction d'un «roi des menestreus», à mettre sans doute en rapport avec les puys ou les confréries de l'époque; dans le Parfait par la transformation même d'Alexandre le Grand en poète durant un concours de ballades. 
4 Didier lechat (Les chevaliers-poètes dans le "Meliador" de Froissart, pp. 71-85) s'interroge sur le rapport instauré par Froissart entre activité poétique et statut du chevalier. Si la plupart des personnages de Meliador, les femmes aussi, composent des pièces lyriques, c'est chez les chevaliers que la poésie s'impose comme un don indissociable tant de leur noblesse que de leur prouesse.

5 Selon Dominique DEMARTINI, à travers le mélange des écritures et des voix, Christine de Pizan poursuit sa critique de l'amour courtois: elle déguise d'abord sa voix derrière celle du Duc, puis se dédouble dans la lettre de Sybille de la Tour, pour dénoncer finalement la fiction d'amour (Figures du poète dans le "Livre du Duc des vrais Amants" de Christine de Pizan ou l'amour démasqué, pp. 87-104). 